\title{
Bathymetric and morphometric surveys of the Montebello Lakes, Chiapas
}

\author{
Javier ALCOCER,${ }^{1 *}$ Luis A. OSEGUERA, ${ }^{1}$ Guillermo SÁNCHEZ, ${ }^{2}$ Circe G. GONZÁLEZ, ${ }^{2}$ Joaquín R. MARTÍNEZ, ${ }^{2}$ \\ Rigel GONZÁLEZ ${ }^{3}$
}

\begin{abstract}
${ }^{1}$ Proyecto de Limnología Tropical, Universidad Nacional Autónoma de México FES Iztacala, Av. de los Barrios No. 1, Los Reyes Iztacala, Tlalnepantla 54090, Mexico; ${ }^{2}$ Programa de Posgrado en Ciencias del Mar y Limnología, Universidad Nacional Autónoma de México; ${ }^{3}$ Licenciatura en Biología, Facultad de Ciencias, Universidad Nacional Autónoma de México

*Corresponding author: jalcocer@unam.mx
\end{abstract}

\begin{abstract}
This study presents the first bathymetric surveys and descriptions of the morphometric parameters of the major lakes of the national park and Ramsar Convention site Lagunas de Montebello, Chiapas, Mexico and represents the first contribution on these limnologically unknown lakes. The morphology of lacustrine basins has an important influence on the physical, chemical and biological dynamics, and limnological research must consider the bathymetry and the related morphometric parameters of the lakes. Of the more than 50 lakes that make up this karst lake system (including dolines, uvalas and poljes), 18 representative lakes were selected along a NW-SE transect. The lakes have widely varying dimensions and include small and deep, small and shallow, large and deep, and large and shallow lakes. The shapes of the lakes vary from circular to elliptical, and the basin resembles an inverted truncated cone. The orientation of the main axis follows the structural orientations of the karst landscape (i.e., faults, fractures and folds). The maximum lengths range from 0.14 to $3.2 \mathrm{~km}$, the surface areas range from $1.1 \mathrm{ha}$ to $306.6 \mathrm{ha}$, and the lake volumes range from 0.00004 to $0.08852 \mathrm{~km}^{3}$. Six lakes are among the deepest lakes in Mexico and have an average maximum depth of more than $50 \mathrm{~m}$; the deepest lake has a maximum depth of $198 \mathrm{~m}$. These depths favor prolonged stratification, which increases the probability of accumulating pollutants.
\end{abstract}

Key words: Bathymetry; morphometry; karst; solution lakes; tropical lakes; Mexico.

Received: April 2015. Accepted: July 2015.

\section{INTRODUCTION}

The morphology of lake basins has important effects on most of the physical, chemical and biological parameters of the lakes. The diverse morphologies of lake basins are a result of their origin and subsequent modifications that are caused by the movement of water within the lake as well as sedimentary inputs from the drainage basin (Wetzel, 2001). The interplay between the physical dimensions of a lake and climatic and edaphic factors determines the environmental conditions of the lake as well as its inhabitants (Cole, 1979). For example, the area of the lake bottom as a function of depth is an important characteristic because a lake that is deep over a large proportion of its area has a delayed biological cycle and is less productive (Margalef, 1983). The morphology of a lake basin greatly regulates the nutrient dynamics, oxygen regime, heat budget and general productivity of the lake (Fee, 1979; Fee et al., 1994). Depth dominates over the natural tendency towards eutrophication (Rawson, 1960) and leads to morphometric oligotrophy (sensu Lundbeck, 1934 in Ryder, 1982). Morphometric parameters must be characterized to identify several limnological processes, such as erosion, nutrient intake rate, mass chemical balance, caloric content, thermal stability, biological productivity and growth effectiveness as well as many structural and functional components of aquatic ecosystems (Wetzel and Likens, 2000).

The Lagunas de Montebello National Park is located in the municipalities of La Trinitaria and Independencia in the state of Chiapas and was declared a protected natural area by a presidential decree that was published by the Diario Oficial de la Federación on December 16, 1959. Subsequently, the area was acknowledged as Ramsar Convention site number 1325 on November 27, 2003. In spite of the name of the national park and Ramsar site (Lagunas de Montebello), the limnological characteristics of the lakes are essentially unknown. Because the shape of the basin determines many of its limnological characteristics and represents basic information that is required for follow-up studies and because only limited information is available for the Chiapas lakes, the goal of this study was to identify the bathymetric and morphometric parameters that are associated with the main water bodies of the Lagunas de Montebello lake complex.

Since this study is strictly exploratory, it does not posit a hypothesis; however, it provides a foundation of information that can be used as the basis of a complete limnological study of the lakes because several changes have occurred to the lakes since 2003, such as a change in the color of the water from crystal clear to yellowish-green 
and the occurrence of a yellowish-white supernatant, fetid odors from sulfur compounds, and fish mortality.

\section{METHODS}

\section{Study area}

The study area covers $64.25 \mathrm{~km}^{2}$ and is located in the physiographic province of Altos de Chiapas, which is also known as the Macizo Central Chiapas. The study area extends from $16^{\circ} 04^{\prime} 40^{\prime \prime} \mathrm{N}$ to $16^{\circ} 10^{\prime} 20^{\prime \prime} \mathrm{N}$ and from $91^{\circ} 37^{\prime} 40^{\prime \prime} \mathrm{W}$ to $91^{\circ} 47^{\prime} 40^{\prime \prime} \mathrm{W}$ (Fig. 1). Hydrologically, the basin is endorheic, is part of the RH30Gl sub-basin of the Comitán River, and is superficially fed by the Grande River. This sub-basin is part of the Lacatún River Basin, which is within hydrological region 30, Grijalva-Usumacinta. Data from the meteorological station in Tziscao $\left(16.1^{\circ} \mathrm{N}, 91.63^{\circ} \mathrm{W} ; 1475 \mathrm{~m}\right.$ asl $)$ indicate that the mean annual temperature is $17.3^{\circ} \mathrm{C}$, the mean annual precipitation is $2,279 \mathrm{~mm}$, and the mean annual evaporation is $948 \mathrm{~mm}$. According to García (1988), the climate of the region is $\mathrm{Cb}(\mathrm{m})(\mathrm{f}) \mathrm{ig}$, which represents a long cool summer that is humid and has a typical summer precipitation regime. More than $10.2 \%$ of the annual precipitation falls during the winter. The climate is isothermal (less than $5^{\circ} \mathrm{C}$ ) of a Ganges type. Lithologically, the entire area of interest is covered by a Lower Cretaceous limestone that is associated with the formation of a lake complex of karst origin; it includes solution lakes (Hutchinson, 1957) with dolines, uvalas and poljes. More than 50 lakes are present in the area. According to the classification of Hutchinson (1957), the dolines (type 43a) are funnel-shaped depressions with varied morphologies from round to elliptical, while some lakes have irregular shapes. The uvalas (type 43b) primarily have elliptical shapes; however, the more developed uvalas may be irregular because they are formed by the coalescence of two or more dolines. The poljes, which are tectono-karstic lakes (type 44) that form mainly by solution in tectonic basins, are elongated and irregular depressions with flat bottoms and steep walls. The dolines, uvalas and poljes are aligned in a NW-SE orientation that coincides with the orientation of the main tectonic units (Durán Calderón, 2013).

Of the $>50$ lakes that make the Lagunas de Montebello karst lake complex, 18 were selected for this study; they cover the entire length of the NW-SE-oriented lake complex. This karst system extends beyond the Mexican border into Guatemala. The following 18 lakes (in alphabetical order) were studied: Agua Tinta (Aguatinta), Balantetic, Bosque Azul, Chajchaj, Cinco Lagos, Dos Lagos (Dos Lagunas), Ensueño, Esmeralda, Kichail, La Encantada, Liq-
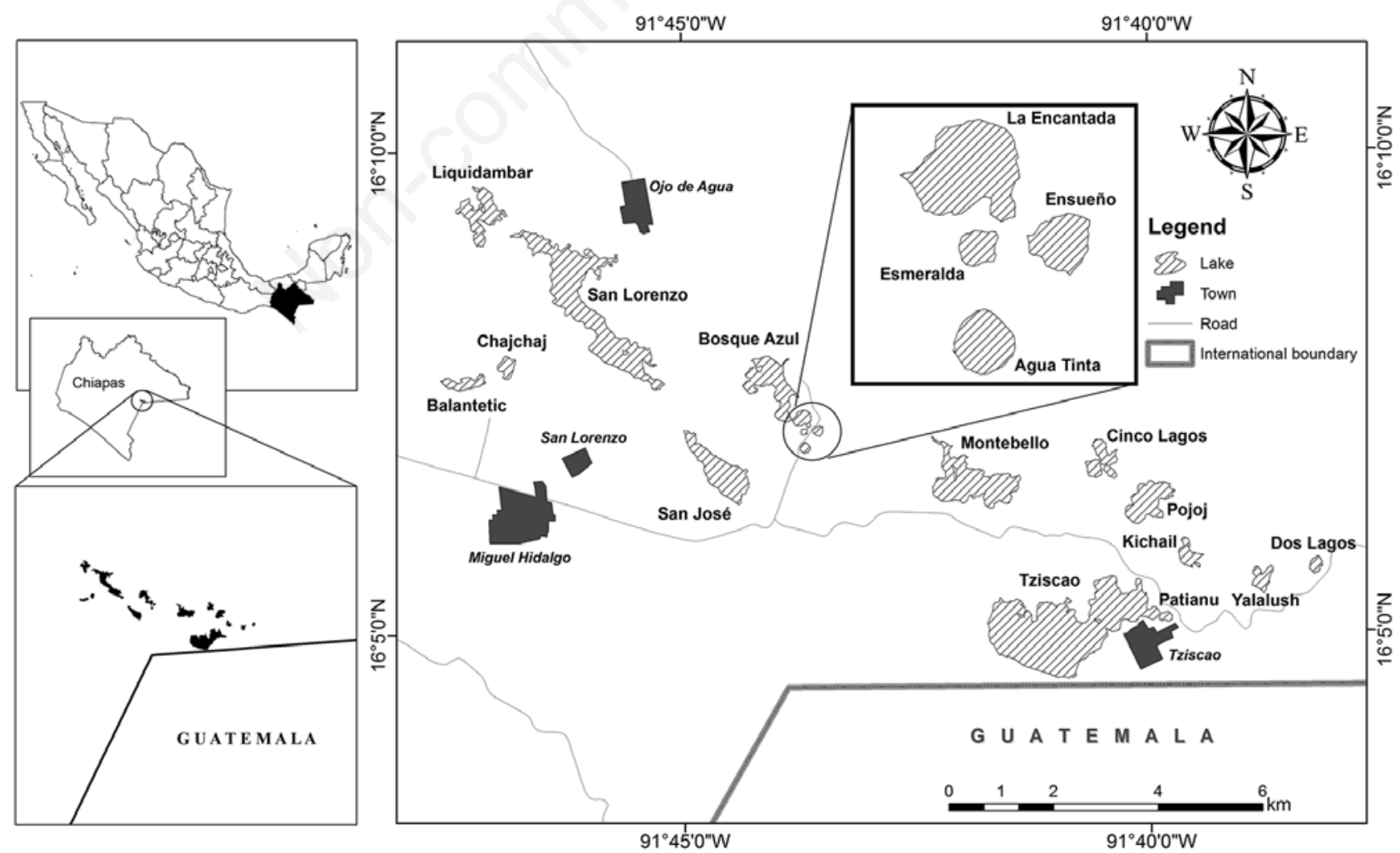

Fig. 1. The Lagunas de Montebello Lake District, Chiapas, Mexico. The lakes in this study are marked. 
uidambar, Montebello, Patianu (Patianú), Pojoj, San José, San Lorenzo, Tziscao and Yalalush (Fig. 1).

\section{Bathymetric survey of the Montebello lakes}

The sampling platform that was used to determine the bathymetry of the lakes was a 10-foot-long (approximately $3 \mathrm{~m}$ ) aluminum boat with a flat bottom that has a 36-inch (approximately $0.9 \mathrm{~m}$ ) beam and a $15-\mathrm{cm}$ water line. A $30 \mathrm{lb}$ thrust Minn Kota (Fargo, North Dakota) electric transom trolling motor was used to propel the boat.

Equidistant transects were conducted on perpendicular grids that covered the entire surface of each lake. The number of transects varied based on the length and width of the lake. Transects were parallel to the maximum length and maximum width of the lakes. The bottom position (latitude, longitude and depth) was recorded using a Garmin (Lenexa, Kansas) echo-sounder model GPSMap $526 \mathrm{~S}$, which was equipped with an external remote antennae to improve satellite signal reception. The geo-positioning has an accuracy of 1-5 $\mathrm{m}$ depending on the number of available satellites (up to 12 available parallel channels) at the time of recording.

The depth sounder has a precision of $95 \%$, a recording speed of $0.5 \mathrm{~m} \mathrm{~s}^{-1}$, a frequency of $200 \mathrm{KHz}$, a cover angle of $8^{\circ}$ and a transmission power of 150 watts (RMS) and 1200 watts (peak to peak). The coastlines were delineated by collecting GPS data (latitude, longitude and elevation) from the boat as it passed around the perimeters of the lakes. This GPS (Garmin GPS model eTrex Vista) has a precision of $<10 \mathrm{~m}(95 \%)$ with an acquisition speed of 0.1 $\mathrm{m} \mathrm{s}^{-1}$. Elevations were obtained by averaging all of the recorded points.

The data that were collected in the field by the Garmin GPSMap 526S echo-sounder and the Garmin GPS eTrex Vista were downloaded with the MapSource software version 8.0, which allows the bottom profiles and the outlines of the lakes to be determined. These data (latitude, longitude and depth) were subsequently exported to a worksheet. The bathymetric charts of the lakes were developed based on the echo-sounder records and outline data. Polygons of the coastlines (perimeters) were delineated based on the outline data using the software ArcGis 10.0 (ESRI Inc., Redlands, CA, USA), and the isobaths of the lakes were obtained using the software Surfer 11.0.642 (Golden Software Inc., Golden, CO, USA). This software was also used to create the XYZ files, which include contour and depth data. The data were interpolated by the kriging geostatistical method, and maps of the lake outlines were obtained with the same software.

\section{Morphometry of the Montebello lakes}

Tab. 1 shows selected morphometric parameters using the nomenclature of Wetzel and Likens (2000). The mor- phometric parameters were calculated using the software ArcGis 10.0 (ESRI Inc.) and Surfer 11.0.642 (Golden Software, Inc.) and the criteria proposed by Wetzel and Likens (2000) except for the index of basin permanence (IBP), which followed the criteria of Kerekes (1977).

A hierarchical cluster analysis (HCA) was performed using the Ward method with the square of the Euclidian distances to classify the Montebello lakes based on their morphology (form and dimensions) using all of the morphometric parameters. In addition, a principal component analysis (PCA) was used to identify the most important parameters for the ordination (García de León Loza, 1988). For the multivariate analyses (HCA and PCA), the morphometric data were Z-transformed to avoid high values that would bias the results and maintain the values within an acceptable scale for comparison (Spatz, 2011). The multivariate analysis and data standardization were performed with the software SPSS v21 (IBM, Armonk, NY, USA).

\section{RESULTS}

Tab. 2 shows the precise coordinates of the limits of the Montebello lakes and Tab. 3 shows the corresponding morphometric parameters. The bathymetric charts of the lakes are provided as supplementary files (Supplementary Figures 1-18).

Based on the orientation of their major axis $\left(\mathrm{L}_{\max }\right)$, most of the lakes have NE-SW (38.9\%) or NW-SE $(33.3 \%)$ orientations, and lower percentages are oriented W-E (16.7\%) and N-S (11.1\%). As shown below, the orientations clearly reflect the structural alignment of the relief. The Montebello lakes have a wide variety of dimensions. The maximum lengths $\left(\mathrm{L}_{\max }\right)$ of the lakes vary between $0.14 \mathrm{~km}$ and $3.2 \mathrm{~km}$ (mean value $(\bar{x})=0.99$ $\mathrm{km})$. The maximum widths $\left(\mathrm{b}_{\max }\right)$ fluctuate between 0.11 $\mathrm{km}$ and $1.48 \mathrm{~km}(\bar{x}=0.55 \mathrm{~km})$, and the mean widths $\left(\mathrm{b}_{\text {mean }}\right)$

Tab. 1. List of measured morphometric parameters, including the symbols and methods of the morphometric characterization, for the Montebello lakes, Chiapas.

\begin{tabular}{lcc} 
Parameter & Symbol & Reference \\
Maximum length & $\mathrm{L}_{\text {max }}$ & ArcGis 10.0 \\
Maximum width & $\mathrm{b}_{\text {max }}$ & ArcGis 10.0 \\
\hline Mean width & $\mathrm{b}_{\text {mean }}$ & Wetzel and Likens (2000) \\
Surface area & $\mathrm{A}$ & ArcGis 10.0 \\
\hline Volume & $\mathrm{V}$ & Wetzel and Likens (2000) \\
Shoreline length & $\mathrm{S}_{\mathrm{L}}$ & ArcGis 10.0 \\
\hline Maximum depth & $\mathrm{Z}_{\text {max }}$ & Wetzel and Likens (2000) \\
Mean depth & $\mathrm{Z}_{\text {mean }}$ & Wetzel and Likens (2000) \\
\hline Relative depth & $\mathrm{Z}_{\mathrm{r}}$ & Wetzel and Likens (2000) \\
Shoreline development & $\mathrm{D}_{\mathrm{L}}$ & Wetzel and Likens (2000) \\
\hline Volume development & $\mathrm{D}_{\mathrm{V}}$ & Wetzel and Likens (2000) \\
Index of basin permanence & $\mathrm{IBP}$ & Kerekes (1977) \\
\hline
\end{tabular}


vary between $0.08 \mathrm{~km}$ and $0.96 \mathrm{~km}(\bar{x}=0.31 \mathrm{~km})$. The perimeters or coastlines $\left(\mathrm{S}_{\mathrm{L}}\right)$ have a mean of $15 \mathrm{~km}$ and vary in length from less than a kilometer $(0.42 \mathrm{~km})$ to more than $15 \mathrm{~km}$ for Esmeralda and San Lorenzo, respectively. The maximum surface area is approximately 306.6 ha at Tziscao, and the lowest is 1.1 ha at Esmeralda. The

Tab. 2. Location (extreme coordinates in decimal degrees and elevations in $\mathrm{m}$ asl) of the Montebello lakes in this study. (The lakes are ordered from west to east).

\begin{tabular}{llllll} 
Name & \multicolumn{5}{c}{ Long $\left({ }^{\circ} \mathbf{W}\right)$} \\
Balantetic & 16.1255 & 16.1284 & 91.7932 & 91.7852 & 1,466 \\
Liquidambar & 16.1505 & 16.1609 & 91.7812 & 91.7903 & 1,461 \\
\hline Chajchaj & 16.1275 & 16.1315 & 91.7798 & 91.7830 & 1426 \\
San Lorenzo & 16.1256 & 16.1533 & 91.7531 & 91.7807 & 1,455 \\
\hline San José & 16.1057 & 16.1185 & 91.7384 & 91.7499 & 1,454 \\
Bosque Azul & 16.1199 & 16.1313 & 91.7290 & 91.7392 & 1,458 \\
\hline Esmeralda & 16.1176 & 16.1186 & 91.7277 & 91.7289 & 1461 \\
Agua Tinta & 16.1144 & 16.1163 & 91.7272 & 91.7291 & 1,465 \\
\hline La Encantada & 16.1189 & 16.1218 & 91.7270 & 91.7307 & 1,454 \\
Ensueño & 16.1173 & 16.1191 & 91.7249 & 91.7268 & 1,430 \\
\hline Montebello & 16.1048 & 16.1172 & 91.6897 & 91.7055 & 1490 \\
Cinco Lagos & 16.1099 & 16.1165 & 91.6724 & 91.6781 & 1,486 \\
\hline Tziscao & 16.0753 & 16.093 & 91.6649 & 91.6957 & 1,490 \\
Patianú & 16.0851 & 16.0867 & 91.6627 & 91.6651 & 1,484 \\
\hline Pojoj & 16.1020 & 16.1095 & 91.6621 & 91.6710 & 1,499 \\
Kichail & 16.0943 & 16.0995 & 91.6570 & 91.6615 & 1,475 \\
\hline Yalalush & 16.0898 & 16.0946 & 91.6447 & 91.6484 & 1,452 \\
Dos Lagos & 16.0932 & 16.0961 & 91.6358 & 91.6382 & \\
\hline
\end{tabular}

Tab. 3. The main morphometric parameters of the Montebello lakes, Chiapas.

\begin{tabular}{|c|c|c|c|c|c|c|c|c|c|c|c|c|c|}
\hline Lake & Orientation & $\begin{array}{l}\mathrm{L}_{\max } \\
(\mathrm{km})\end{array}$ & $\begin{array}{l}\mathbf{b}_{\max } \\
(\mathrm{km})\end{array}$ & $\begin{array}{l}\mathrm{b}_{\text {mean }} \\
(\mathrm{km})\end{array}$ & $\begin{array}{c}\text { A } \\
\text { (ha) }\end{array}$ & $\begin{array}{c}\mathrm{S}_{\mathrm{L}} \\
(\mathrm{km})\end{array}$ & $\begin{array}{c}\mathrm{V} \\
\left(\mathrm{km}^{3}\right)\end{array}$ & $\begin{array}{l}Z_{\max } \\
(\mathrm{m})\end{array}$ & $\begin{array}{l}\mathbf{Z}_{\text {mean }} \\
(\mathrm{m})\end{array}$ & $\begin{array}{c}\mathrm{Z}_{\mathrm{r}} \\
(\%)\end{array}$ & $D_{L}$ & $\mathrm{D}_{\mathrm{v}}$ & IBP \\
\hline Agua Tinta & $\mathrm{N}-\mathrm{S}$ & 0.21 & 0.20 & 0.14 & 3.0 & 0.65 & 0.00044 & 24 & 14.7 & 13.7 & 1.07 & 1.81 & 0.670 \\
\hline Balantetic & W-E & 0.81 & 0.23 & 0.17 & 13.6 & 2.33 & 0.00023 & 3 & 1.7 & 0.7 & 1.79 & 1.65 & 0.099 \\
\hline Bosque Azul & NW-SE & 1.32 & 0.82 & 0.40 & 52.5 & 5.81 & 0.01050 & 58 & 20.0 & 7.1 & 2.26 & 1.04 & 1.808 \\
\hline Chajchaj & $\mathrm{N}-\mathrm{S}$ & 0.45 & 0.31 & 0.21 & 9.2 & 1.33 & 0.00048 & 12 & 5.3 & 3.5 & 1.23 & 1.30 & 0.365 \\
\hline Cinco Lagos & NW-SE & 0.82 & 0.60 & 0.29 & 23.7 & 3.78 & 0.01006 & 162 & 42.5 & 29.5 & 2.19 & 0.79 & 2.660 \\
\hline Dos Lagos & NE-SW & 0.34 & 0.23 & 0.16 & 5.2 & 0.99 & 0.00132 & 42 & 25.2 & 16.4 & 1.22 & 1.78 & 1.341 \\
\hline Ensueño & NE-SW & 0.22 & 0.19 & 0.12 & 2.7 & 0.66 & 0.00058 & 35 & 21.6 & 19.0 & 1.13 & 1.84 & 0.884 \\
\hline Esmeralda & NE-SW & 0.14 & 0.11 & 0.08 & 1.1 & 0.42 & 0.00004 & 7 & 3.6 & 5.8 & 1.11 & 1.57 & 0.097 \\
\hline Kichail & NW-SE & 0.58 & 0.44 & 0.21 & 12.5 & 2.38 & 0.00119 & 22 & 9.5 & 5.5 & 1.90 & 1.29 & 0.499 \\
\hline La Encantada & W-E & 0.39 & 0.31 & 0.21 & 8.2 & 1.28 & 0.00241 & 89 & 29.4 & 27.5 & 1.26 & 0.99 & 1.880 \\
\hline Liquidambar & NW-SE & 0.95 & 0.70 & 0.43 & 40.5 & 5.68 & 0.00453 & 24 & 11.2 & 3.3 & 2.52 & 1.42 & 0.797 \\
\hline Montebello & NE-SW & 1.69 & 1.14 & 0.57 & 96.2 & 7.84 & 0.01186 & 45 & 12.3 & 4.0 & 2.26 & 0.83 & 1.513 \\
\hline Patianu & W-E & 0.26 & 0.18 & 0.13 & 3.4 & 0.73 & 0.00037 & 26 & 10.8 & 12.5 & 1.12 & 1.25 & 0.504 \\
\hline Pojoj & NE-SW & 1.06 & 0.74 & 0.41 & 43.7 & 3.61 & 0.01538 & 198 & 35.2 & 41.6 & 1.54 & 0.53 & 4.258 \\
\hline San José & NW-SE & 1.76 & 0.66 & 0.34 & 60.6 & 4.54 & 0.00623 & 30 & 10.3 & 7.3 & 1.64 & 1.03 & 1.372 \\
\hline San Lorenzo & NW-SE & 3.09 & 1.29 & 0.59 & 181.3 & 15.01 & 0.02147 & 67 & 11.8 & 4.4 & 3.14 & 0.53 & 0.001 \\
\hline Tziscao & NE-SW & 3.20 & 1.48 & 0.96 & 306.6 & 13.22 & 0.08852 & 86 & 28.9 & 11.7 & 2.13 & 1.00 & 6.695 \\
\hline Yalalush & NE-SW & 0.54 & 0.33 & 0.21 & 11.5 & 1.87 & 0.00114 & 23 & 9.9 & 19.6 & 1.56 & 1.29 & 0.607 \\
\hline $\mathrm{X}$ & & 0.99 & 0.55 & 0.31 & 48.6 & 4.01 & 0.00982 & 53 & 16.9 & 12.9 & 1.73 & 1.22 & 1.447 \\
\hline Max & & 3.20 & 1.48 & 0.96 & 306.6 & 15.01 & 0.08852 & 198 & 42.5 & 41.6 & 3.14 & 1.84 & 6.695 \\
\hline Min & & 0.14 & 0.11 & 0.08 & 1.1 & 0.42 & 0.00004 & 3 & 1.7 & 0.7 & 1.07 & 0.53 & 0.001 \\
\hline
\end{tabular}

$L_{\max }$ maximum length; $b_{\max }$ maximum width; $b_{\text {mean }}$, mean width; $A$, surface area; $V$, volume; $S_{L}$, shoreline length; $Z_{\text {max }}$ maximum depth; $Z_{\text {mean }}$, mean depth; $Z_{p}$ relative depth; $D_{L}$, shoreline development; $D_{b}$ volume development; IPB, index of basin permanence. 
mean surface area is 48.6 ha. Esmeralda has the lowest water volume $\left(0.040 \mathrm{hm}^{3}\right)$, whereas Tziscao has the maximum volume of $88.521 \mathrm{hm}^{3}\left(\bar{x}=9.819 \mathrm{hm}^{3}\right)$. The maximum depth $\left(Z_{\max }\right)$ recorded in the Montebello lakes is 198 $\mathrm{m}$ at Pojoj followed by $161.8 \mathrm{~m}$ at Cinco Lagos. In contrast, several lakes are shallow, such as Balantetic $(3 \mathrm{~m})$ and Esmeralda (7 m); the average depth is $53 \mathrm{~m}$. The average of the mean depths $\left(Z_{\text {mean }}\right)$ is $16.9 \mathrm{~m}$, and the minimum mean depths are also at Balantetic $(1.7 \mathrm{~m})$ and Esmeralda (3.6 m), whereas Cinco Lagos has the maximum mean depth $(42.5 \mathrm{~m})$.

Figs. 2 and 3 show the distribution (from largest to smallest) of the lakes based on their morphometric parameters. The white bars indicate lakes with magnitudes that are greater than the global mean, and the black bars indi- cate lakes with magnitudes that are less than the global mean. The distribution is log-normal; approximately one third of the lakes (6-8) have distributions that are greater than the mean, whereas two thirds of the lakes (10-13) are less than the mean. The only morphometric parameter that does not conform to this trend is the volume development $\left(D_{V}\right)$, for which 11 of the lakes are greater than the mean; thus, the lakes have conical shapes, which is typical of karst lakes. In the HCA dendrogram, which was constructed with the morphometric parameters, three groups are observed with a cut at half the similarity distance. The first group (A) contains the largest number of lakes, which are clustered into three groups with Agua Tinta isolated. The second group (B) contains three lakes, which is the smallest number of lakes, and the third group (C) contains
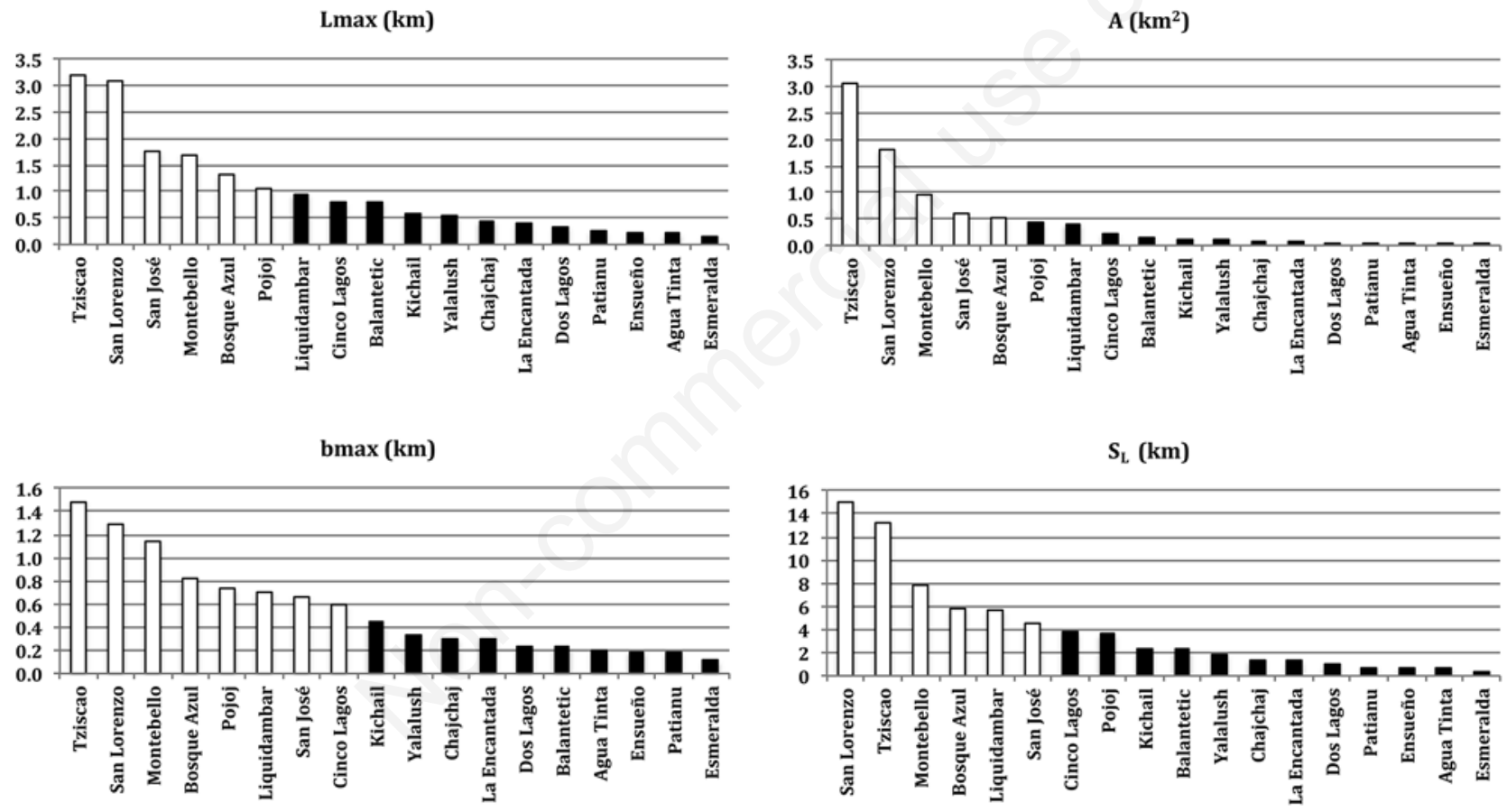

bmean (km)
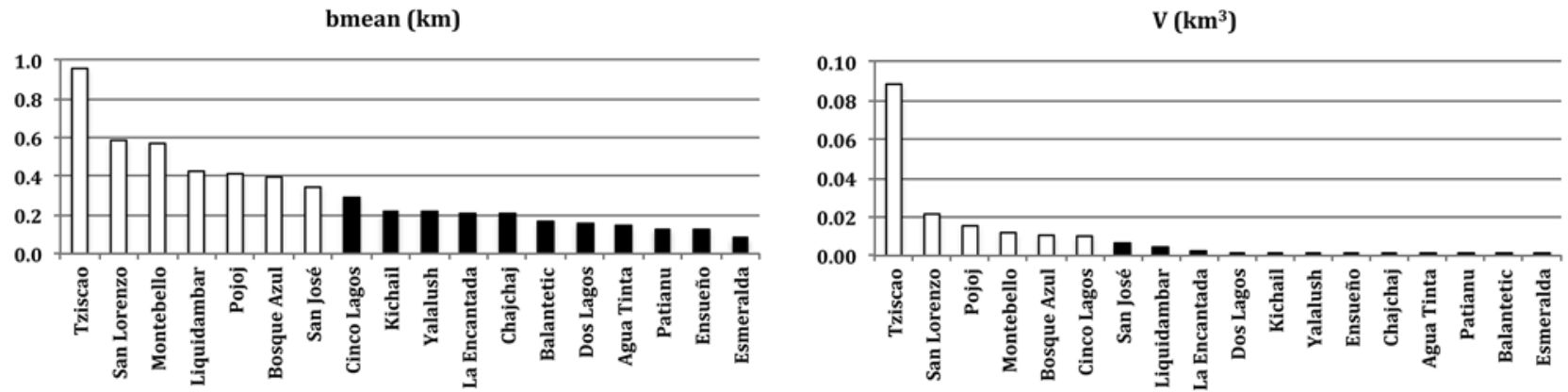

Fig. 2. Graphical representation of the dimensions of the sampled Montebello lakes from greatest to smallest based on their morphometric measurements. White bars, values greater than the mean; black bars, values less than the mean; $\mathrm{L}_{\max }$, maximum length; $b_{\max }$, maximum width; $b_{\text {mean }}$, mean width; $A$, surface area; $V$, volume; $\mathrm{S}_{\mathrm{L}}$, coastline or perimeter. 
five lakes, of which Tziscao is the least similar to the others (Fig. 4). In the PCA, the first two principal components (PC) explain almost $70 \%$ of the total variance (68.9\%); the first PC explains $47.8 \%$. For PC $1, b_{\max }$ and $\mathrm{b}_{\text {mean }}$ were the most heavily loaded variables $(0.156$ and 0.154 , respectively). The widest lakes are in the positive part of the first PC. However, the relative depth $\left(Z_{r}, 0.355\right)$ and the mean depth $\left(Z_{\text {mean }}, 0.353\right)$ had the greatest influence on PC2. The highest values of these variables are in the positive part of the component. The same three groups as in the HCA are identified in the PCA. Group A includes lakes with the lowest values of $b_{\text {max }}, b_{\text {mean }}, Z_{\text {mean }}$ and $Z_{r}$. Group $B$ includes lakes with the largest values of $Z_{\text {mean }}$ and $Z_{r}$, and group $C$ contains lakes with the largest values of $b_{\max }$ and $b_{\text {mean }}$ (Fig. 5).

Zmax (m)

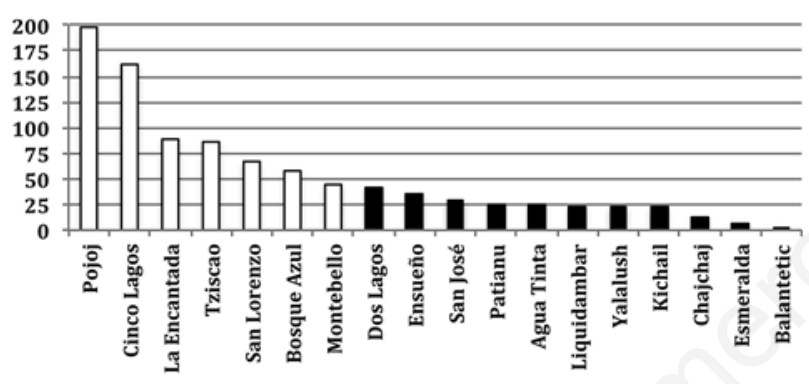

Zmean (m)

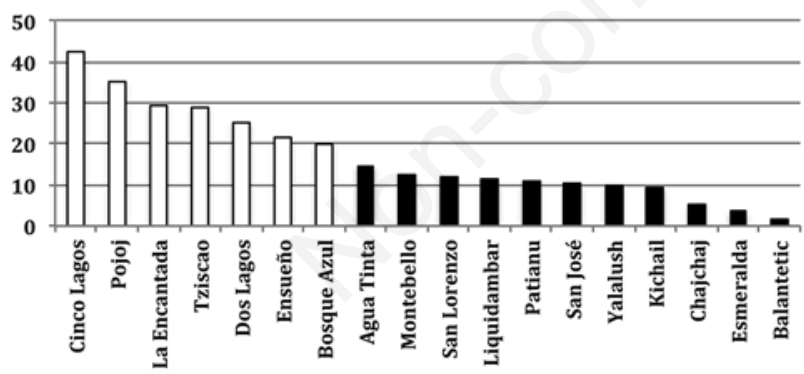

$\operatorname{Zr}(\%)$

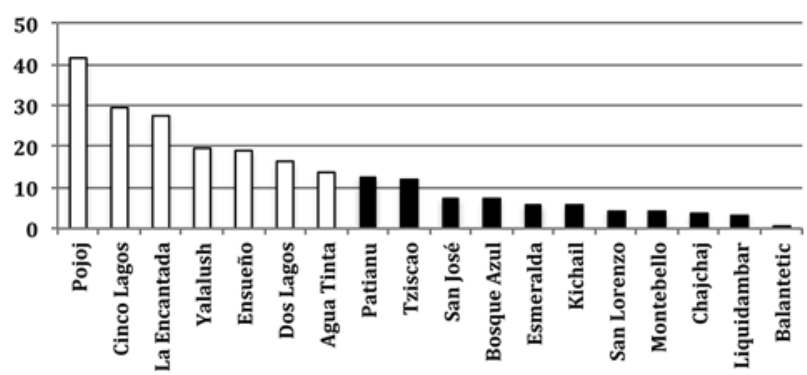

\section{DISCUSSION}

The Montebello lakes include several types of solution lakes or karst structures, including dolines (Type 43a from the classification of Hutchinson, 1957), uvalas (Type 43b) and poljes (Type 54), which have an increasing degree of dissolution and structural complexity. The directions of the major axes of the lakes are consistent with the structural alignments of the relief (faults, fractures and folds), which indicates a close relationship with the main tectonic alignments and fracture network (Durán Calderón, 2013). Based on the bathymetry, the Montebello lakes can be classified into the three categories of karst lakes (Tab. 4). In addition, the lakes can be classified into two groups based on their main dimensions $\left[\mathrm{L}_{\max }, \mathrm{b}_{\text {max }}, \mathrm{b}_{\text {mean }}, \mathrm{A}\right.$ (sur-

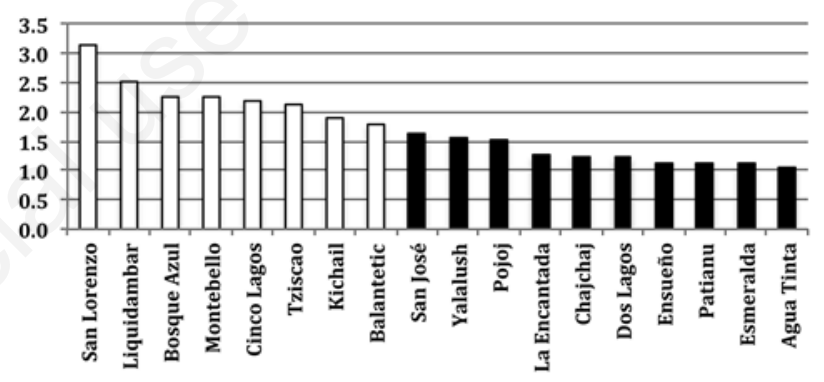

$D_{\mathrm{v}}$

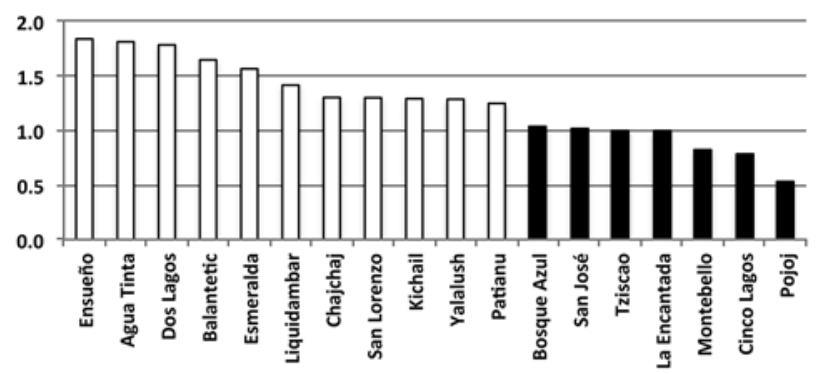

IBP

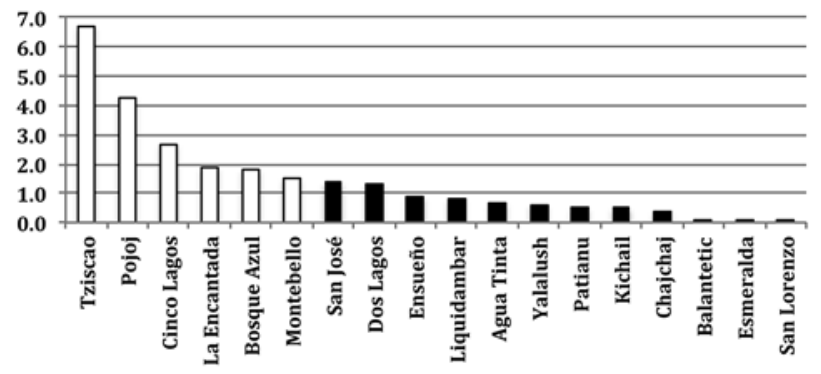

Fig. 3. Graphical representation of the sampled Montebello lakes from greatest to smallest based on their morphometric measurements. White bars, values greater than the mean; black bars, values less than the mean; $Z_{\text {max }}$, maximum depth; $Z_{\text {mean }}$, mean depth; $Z_{r}$, relative depth; $D_{L}$, development of the coastline; $D_{v}$, development of volume; IBP, index of basin permanence. 
face area), $\mathrm{S}_{\mathrm{L}}$ (shoreline length), and $\mathrm{V}$ (volume)]: a) large lakes, where all or most (at least four out of six) measurements are greater than the mean, and b) small lakes, where all or most of the dimensions (at least three) are less than the mean. The large lakes are Bosque Azul, Montebello, Pojoj, San José, San Lorenzo and Tziscao, and the small lakes are Agua Tinta, Balantetic, Chajchaj, Cinco Lagos, Dos Lagos, Ensueño, Esmeralda, Kichail, La Encantada, Liquidambar, Patianu and Yalalush. The lakes are also divided into two groups based on their depths $\left(Z_{\text {max }}, Z_{\text {mean }}\right.$ and $\mathrm{Z}_{\mathrm{r}}$ ): a) deep lakes, in which the values of at least two of the three parameters are greater than the mean, and b) shallow lakes, with parameter values that are less than the mean. The deep lakes are Bosque Azul, Cinco Lagos, Dos Lagos, Ensueño, La Encantada, Pojoj and Tziscao, and the shallow lakes are Agua Tinta, Balantetic, Chajchaj, Esmeralda, Kichail, Liquidambar, Montebello, Patianu, San José, San Lorenzo and Yalalush. In summary, the Montebello lakes are classified into four categories based on their dimensions and depth (Tab. 5). This simple classification, which only considers a few morphometric variables, is consistent with the multivariate analyses (HCA and PCA), where the lakes were classified in three groups according to their dimensions (represented mainly by $b_{\max }$ and $\mathrm{b}_{\text {mean }}$ ) and depths (represented mainly by $\mathrm{Z}_{\mathrm{r}}$ and $\mathrm{Z}_{\text {mean }}$ ). However, each type of lake (dolines, uvalas and poljes) has a wide range of values, so it appears that the mode of origin has little influence on the morphometry (i.e., the HCA and PCA groups do not appear to be related to the mode of origin). The geomorphological study of Durán Calderón (2013) provides information that may explain this lack of concordance. While one group of lakes is closely related to the main fracture network in the area, the other is more closely related to the solution and collapse of ancient caverns. Furthermore, it appears that most

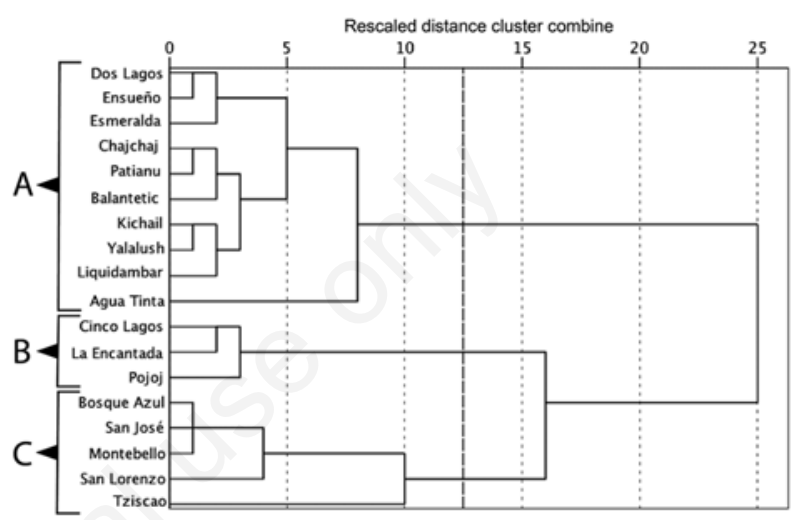

Fig. 4. Classification (Hierarchical Cluster Analysis, Ward method) of the Montebello lakes, Chiapas, based on their morphometric parameters.

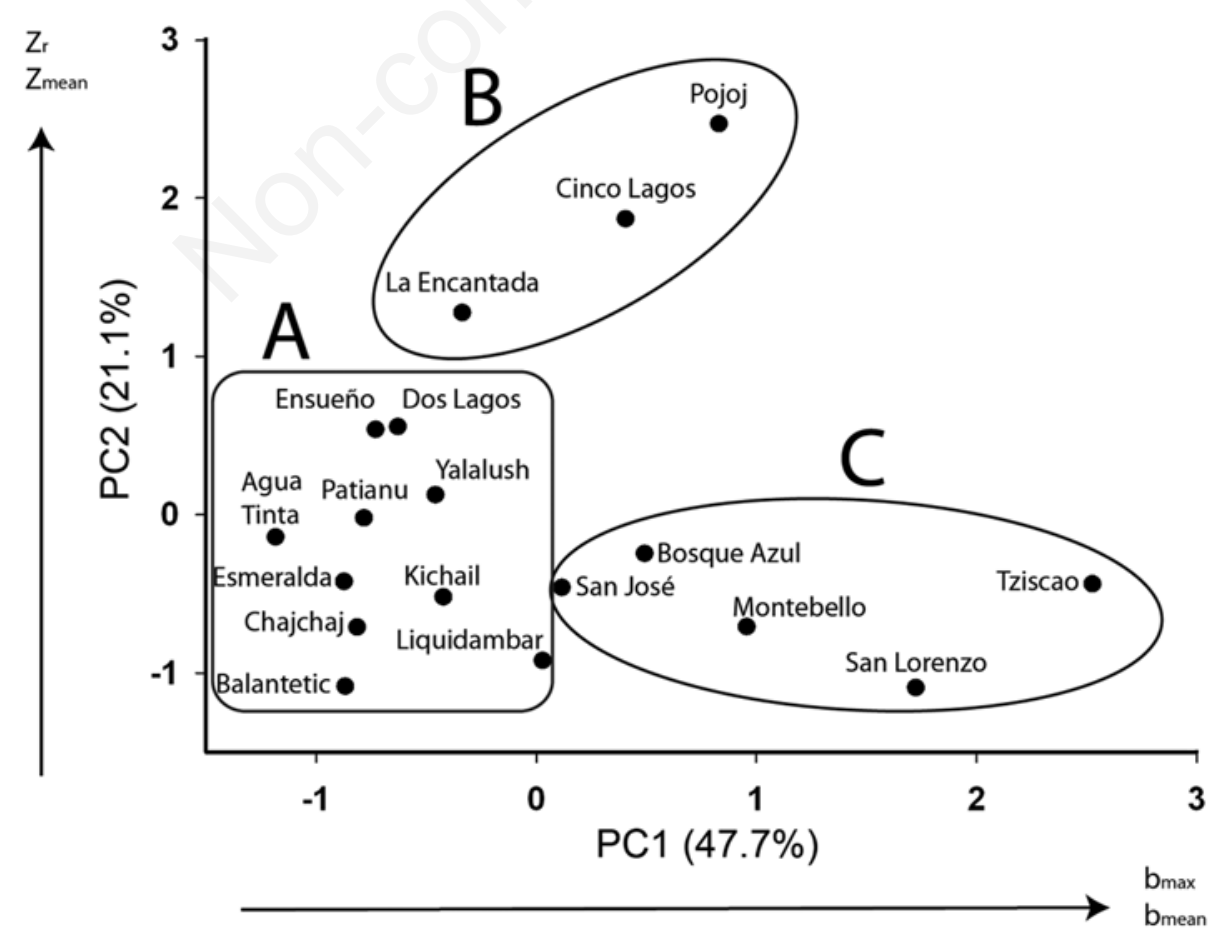

Fig. 5. Ordination (Principal Components Analysis) of the Montebello lakes, Chiapas based on their morphometric parameters. 
of the dolines developed on Cretaceous strata, the uvalas formed on Cretaceous and Quaternary strata, and the poljes formed on Quaternary strata.

As previously described, some of the Montebello lakes are deep. Five of the 18 Montebello lakes in this study are the second to sixth deepest $\left(\mathrm{Z}_{\max }\right)$ in Mexico. The deepest lake in Mexico is called El Zacatón; it formed from a hydrothermal karst, is $339 \mathrm{~m}$ deep and is located in the municipality of Aldama, NE of Tamaulipas (Gary et al., 2008). The next deepest lakes are Pojoj $(198 \mathrm{~m})$, Cinco Lagos (162 m), La Encantada (89 m), Tziscao (86 $\mathrm{m})$ and San Lorenzo $(67 \mathrm{~m})$. The next two deepest lakes are crater lakes or maars: Santa María del Oro in Nayarit (65.5 m; Serrano et al., 2002) and Alchichica in Puebla (62 m; Filonov et al., 2006).

In general, $Z_{\max }$ is positively correlated to $Z_{\text {mean }}$ (the larger the value of $Z_{\max }$, the larger the value of $Z_{\text {mean }}$ ) (Fig. 6). Pojoj had the largest $Z_{\max }(198 \mathrm{~m})$, but $Z_{\text {mean }}$ was only $35 \mathrm{~m}$, which differs from the general trend (dotted line in Fig. 6). However, Pojoj had the second highest value of $Z_{\text {mean }}$. The average $Z_{\max }$ of all of the Montebello lakes was equal to only $27 \%$ of the largest $Z_{\max }$. A similar relationship for $Z_{\text {mean }}$ shows that the mean value of $Z_{\text {med }}$ is $40 \%$ of the maximum $Z_{\text {med. }}$. In most lakes around the world, $Z_{\mathrm{r}}<2 \% ; \mathrm{Z}_{\mathrm{r}}>4 \%$ indicates a deep lake with a small surface area, which reflects resistance to mixing (Hutchinson, 1957; Wetzel and Likens, 2000). The Montebello lakes have a mean $\mathrm{Z}_{\mathrm{r}}$ of $12.9 \%$ and show a marked trend towards stratification. The highest values of $Z_{r}$ above the mean are at Agua Tinta, Cinco Lagos, Dos Lagos, Ensueño, La Encantada, Pojoj and Yalalush, and Balantetic has the lowest value $(0.7 \%)$. The $\mathrm{D}_{\mathrm{L}}$ values indicate that most of the Montebello lakes are nearly circular $(\approx 1)$, including Agua Tinta $\left(\mathrm{D}_{\mathrm{L}}=1.07\right)$, or subcircular to elliptical $(\approx 2)$, although some lakes are more irregular, such as San Lorenzo $\left(D_{L}=3.14\right)$. The mean $D_{L}$ value of the lakes is 1.73. Irregular coastlines (high values of $\mathrm{D}_{\mathrm{L}}$ ) favor the growth of littoral macrophytes and general productivity of the lake (Hutchinson, 1957). This parameter indicates the potential habitat that is available for wildlife in the lake. The highest values above the mean $\mathrm{D}_{\mathrm{L}}$ are at Balantetic, Bosque Azul, Cinco Lagos, Kichail, Liquidambar, Montebello, San Lorenzo and Tziscao.

According to Hutchinson (1957), most of the lakes have a development of volume $\left(D_{V}\right)>1$, which indicates a conical depression. Lakes that are located on rocks that are easily eroded have $D_{V}$ values between 1 and 1.5. These conditions occur in the Montebello lakes because they are karst type lakes, and only five (Cinco Lagos, La Encantada, Montebello, Pojoj and San Lorenzo) of the 18 lakes

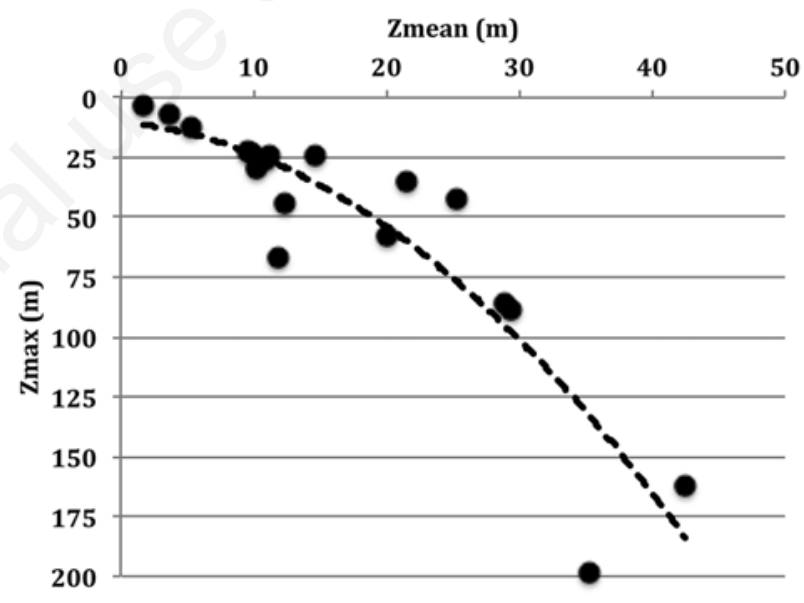

Fig. 6. Relationship between $Z_{\max }$ and $Z_{\text {mean }}$ for the Montebello lakes (the dotted line indicates the general trend).

Tab. 4. Classification of the type of origin (Hutchinson 1957) of the Montebello lakes based on the morphometric parameters.

\begin{tabular}{ll} 
Category & Lakes \\
Doline & Agua Tinta, Dos Lagos, Ensueño, Esmeralda and Patianu \\
Uvala & Chajchaj, Balantetic, Cinco Lagos, Bosque Azul, La Encantada, Liquidambar, Kichail, Montebello, Pojoj, Yalalush and San José \\
\hline Polje & San Lorenzo and Tziscao \\
\hline
\end{tabular}

Tab. 5. Categorization of the Montebello lakes based on their dimensions and depths.

\begin{tabular}{ll} 
Category & Lakes \\
Large and deep & Bosque Azul, Pojoj, Tziscao \\
Large and shallow & Montebello, San José, San Lorenzo \\
\hline Small and deep & Cinco Lagos, Dos Lagos, Ensueño, La Encantada \\
Small and shallow & Agua Tinta, Balantetic, Chajchaj, Esmeralda, Kichail, Liquidambar, Patianu, Yalalush \\
\hline
\end{tabular}


have $\mathrm{D}_{\mathrm{V}}<1$, although La Encantada (0.99), Bosque Azul (1.04), San José (1.03) and Tziscao (1.0) are close to $D_{V}=1$. Pojoj has the lowest $D_{V}(0.53)$, which clearly identifies it as having a small deep area. IBP values below 0.1 reflect senescent lakes that are dominated by rooted aquatic vegetation (Kerekes, 1977). The most extreme case is San Lorenzo, which has an IBP of 0.001, although Balantetic (0.099) and Esmeralda (0.097) are similar. At values of 0.2 , lakes show an improved permanence, but large and deep lakes have much higher IBP values (e.g., Lake Erie at 450 or Lake Superior at 4,000). The Montebello lakes have a mean IBP of 1.5 and show permanence, and Tziscao has the maximum IBP of 6.7. The lakes with the greatest permanence and values above the mean are Bosque Azul, Cinco Lagos, La Encantada, Montebello, Pojoj and Tziscao.

\section{CONCLUSIONS}

- The Montebello lakes formed by the dissolution of the material on which they are located, and they include dolines, uvalas and poljes. The orientation of the main axes of the lakes is consistent with the structural alignment of the karst relief (faults, fractures, and folds).

- The lakes have widely varying morphometric dimensions, including large and deep, large and shallow, small and deep, and small and shallow lakes.

- The maximum and mean widths and the relative and mean depths are the morphometric parameters that best distinguish the lakes. Based on these parameters, the 18 lakes that were surveyed were separated into three groups: a) lowest width and depth (Agua Tinta, Esmeralda, Chajchaj, Balantetic, Patianu, Ensueño, Dos Lagos, Yalalush, Kichail and Liquidambar), b) deepest (La Encantada, Cinco Lagos, Pojoj), and c) widest (San José, Bosque Azul, Montebello, San Lorenzo and Tziscao).

- The maximum lengths vary from 0.14 to $3.20 \mathrm{~km}$, the surface areas vary from 1.1 to 306.6 ha, and the volumes vary from 0.040 to $88.521 \mathrm{hm}^{3}$.

- Six of the 18 Montebello lakes are among the deepest in Mexico; they are the second to sixth deepest behind El Zacatón, which is located in Tamaulipas and is of hydrothermal karst origin.

- Most of the Montebello lakes have high $Z_{r}$ values, which reflect a marked tendency towards stratification.

- The $\mathrm{D}_{\mathrm{L}}$ values indicate that most of the Montebello lakes have circular to sub-circular and elliptical shapes, and the $D_{v}$ values indicate that the basin has a conical shape; both characteristics are expected based on the origin of the lakes.

- The IBP values indicate that most of the Montebello lakes have high permanence; therefore, they are not considered senescent lakes.

\section{ACKNOWLEDGMENTS}

This research was funded by the Fondo Sectorial de Investigación y Desarrollo Sobre el Agua (Sectorial Fund for Water Research and Development) (CONAGUACONACYT) through the project Estudio hidrológico y de Calidad del Agua del sistema Lagunar de Montebello, en el estado de Chiapas and by Dirección General de Asuntos del Personal Académico (PAPIIT-IN219215) through the project Factores que determinan el estado trófico de los lagos de Montebello, Chiapas. We thank René Morales Hernández for support during the fieldwork. We also thank the Parque Nacional Lagunas de Montebello, Comisión Nacional de Áreas Naturales Protegidas (CONANP) (Jesús A. León and Roberto Castellanos), the local community, and the Comisariados Ejidales from Antelá, Cárdenas, Miguel Hidalgo, Ojo de Agua and Tziscao for facilitating access to the lakes. We also thank the Comité de Administración de Tziscao (Sergio Marcos and Miguel A. Tomas), Presidente del Comité de Turismo de Tziscao (Armando Hernández), Comisario Ejidal de Tziscao (Enrique M. Hernández) and personnel of the Villas Tziscao Hotel (Rosemberg F. Jorge, Juan G. Espinoza and Gemuel P. Hernández) for offering their support and facilities for this study.

\section{REFERENCES}

Cole GA, 1979. Textbook of limnology. Mosby, St. Louis: 426 pp. Durán Calderón JL, 2013. [Análisis geomorfológico del Parque Nacional Lagunas de Montebello, Chiapas].[Thesis in Spanish]. UNAM, México: 89 pp.

Fee EJ, 1979. A relation between lake morphometry and primary productivity and its use in interpreting whole-lake eutrophication experiments. Limnol. Oceanogr. 24:401-416.

Fee EJ, Hecky RE, Regehr GW, Hendzel LL, Wilkinson P, 1994. Effects of lake size on nutrient availability in the mixed layer during summer stratification. Can. J. Fish. Aquat. Sci. 51:2756-2768.

Filonov A, Tereshchenko I, Alcocer J, 2006. Dynamic response to mountain breeze circulation in Alchichica, a crater lake in Mexico. Geophys. Res. Lett. 33:L07404.

García E, 1988. [Modificaciones al sistema de clasificación climática de Köppen].[Book in Spanish]. Instituto de Geografía, UNAM: 217 pp.

García de León Loza A, 1988. [Generalidades de análisis de cúmulos y de análisis de componentes principals].[Article in Spanish]. Divulgación Geográfica 8:7-29.

Gary M, Fairfield N, Stone WC, Wettergreen D, Kantor GA, Sharp Jr. JM, 2008. 3D mapping and characterization of Sistema Zacatón from DEPTHX (DEep Phreatic THermal eXplorer), p. 202-212. Proc. 11th Multidisciplinary Conf. on Sinkholes and the engineering and environmental impacts of karst, Tallahassee, FL, USA.

Hutchinson GE, 1957. A treatise on limnology. 1. J. Wiley \& Sons, New York: 1015 pp.

Kerekes J, 1977. The index of lake basin permanence. Int. Rev. Ges. Hydrobiol. Hydrogr. 62:291-293. 
Margalef R, 1983. [Limnología].[Book in Spanish]. Omega, Barcelona: $1010 \mathrm{pp}$.

Rawson DS, 1960. A limnological comparison of twelve large lakes in northern Saskatchewan. Limnol. Oceanogr. 5:195-211.

Ryder RA, 1982. The morphoedaphic index - use, abuse, and fundamental concepts. Trans. Am. Fish. Soc. 111:154-164.

Serrano D, Filonov A, Tereshchenko I, 2002. Dynamic response to valley breeze circulation in Santa María del Oro, a vol- canic lake in Mexico. Geophys. Res. Lett. DOI:10.1029/ 2001 GL014142.

Spatz C, 2011. Basic statistics: tales of distributions. Wadsworth Cengage Learning, Belmont: $512 \mathrm{pp}$.

Wetzel RG, Likens GE, 2000. Limnological analyses. Springer, New York: 429 pp.

Wetzel RG, 2001. Limnology: lake and river ecosystems. Academic Press, San Diego: 1006 pp. 